\title{
Correction to: Quantifying the extent of fistulotomy. How much sphincter can we safely divide? A three-dimensional endosonographic study
}

\author{
Marina Garcés-Albir ${ }^{1}$. Stephanie Anne García-Botello ${ }^{1}$ • Pedro Esclapez-Valero ${ }^{1}$. Angel Sanahuja-Santafé ${ }^{1}$. \\ Juan Raga-Vázquez ${ }^{1}$ • Alejandro Espi-Macías ${ }^{1}$. Joaquín Ortega-Serrano ${ }^{1}$
}

Published online: 22 June 2019

(C) Springer-Verlag GmbH Germany, part of Springer Nature 2019

Correction to: Int J Colorectal Dis (2012) 27:1109-1116

https://doi.org/10.1007/s00384-012-1437-3

In the Figure 1 of the original published version of this article the numbers were switched. The number of Intersphincteric Fistulas should be $\mathbf{n = 1 2}$ and of Low Transphincteric Fistulas should be $\mathbf{n = 2 3}$. Accordingly, in the text of Results section, lines 5 and 6 the numbers were also interchanged. The respective text in the result part should be changed to "The low transphincteric fistula was the most common type (23 cases) followed by intersphincteric tracts (12 cases) as shown in Fig. 1."
The online version of the original article can be found at https://doi.org/ 10.1007/s00384-012-1437-3

Marina Garcés-Albir

garalma@hotmail.com

Stephanie Anne García-Botello

stephaniegarcia@telefonica.net

Pedro Esclapez-Valero

pedro.esclapez@uv.es

Angel Sanahuja-Santafé

coloproc_hcv@gva.es
Juan Raga-Vázquez

juanragavazquez@hotmail.es

Alejandro Espi-Macías

alejandro.espi@uv.es

Joaquín Ortega-Serrano

joaquin.ortega@uv.es

Department of General and Digestive Surgery, Colorectal Unit, Hospital Clínico Universitario, HCUV. Avd. Blasco Ibañez, 17, 46010 Valencia, Spain 


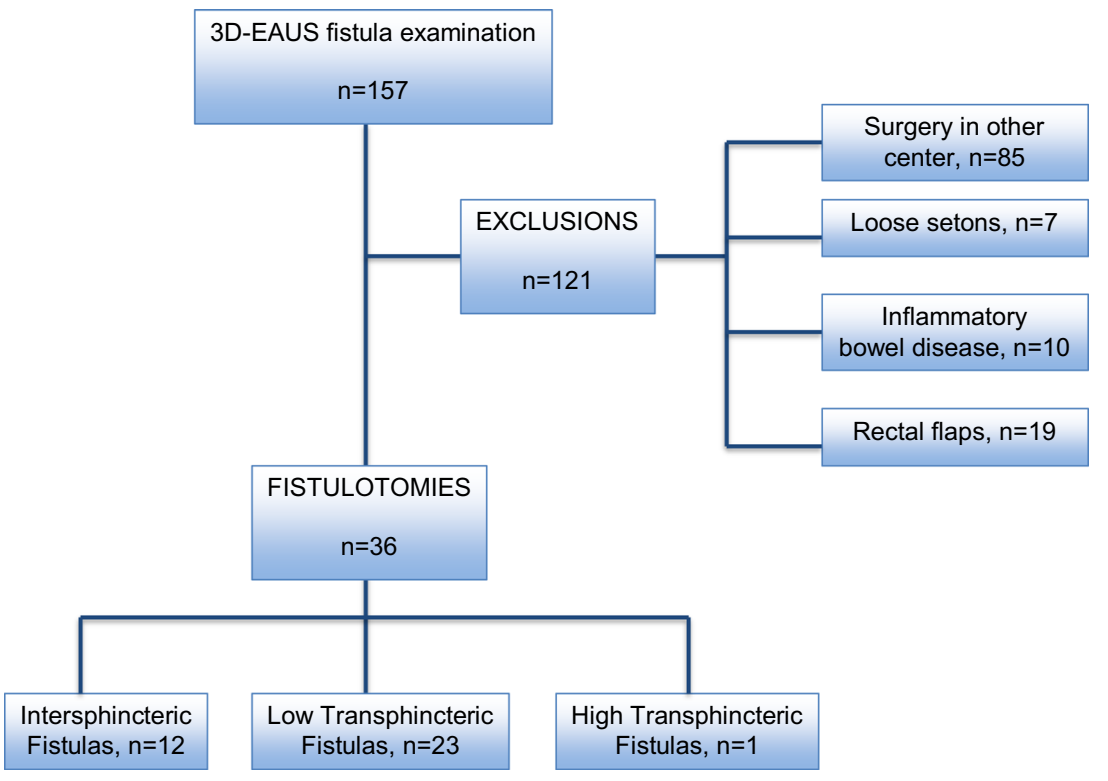

Fig. 1 Distribution of patients

Publisher's note Springer Nature remains neutral with regard to jurisdictional claims in published maps and institutional affiliations. 